\title{
PENGARUH KADAR GLUKOSA TERHADAP EKSPRESI PROTEIN Adh036 BAKTERI Salmonella Typhi
}

\author{
Sri Winarsih ${ }^{\star \varpi}$, Hidayat Sujuti**, Aulia Yasmin*
}

\begin{abstract}
Abstrak
Demam tifoid yang disebabkan oleh Salmonella Typhi merupakan salah satu penyakit infeksi terbanyak penyebab rawat inap penderita di Indonesia. Sehingga diperlukan penelitian tentang faktor-faktor yang mempengaruhi patogenesitas dari S.Typhi salah satunya adalah kadar glukosa. S. Typhi diketahui memiliki molekul adhesin pada bagian outer membrane protein (OMP) dengan berat molekul $36 \mathrm{kDa}$ atau disebut juga Adh036. Molekul adhesin ini berfungsi sebagai perlekatan bakteri pada sel hospes. Pada penelitian ini ingin diketahui pengaruh kadar glukosa terhadap ekspresi protein Adh036 OMP S. Typhi. Perlakuan glukosa diberikan pada lima kelompok bakteri yaitu konsentrasi $40 \mathrm{mg} / 100 \mathrm{~mL}, 80 \mathrm{mg} / 100 \mathrm{~mL}, 160 \mathrm{mg} / 100 \mathrm{~mL}, 240$ $\mathrm{mg} / 100 \mathrm{~mL}$ dan $320 \mathrm{mg} / 100 \mathrm{~mL}$. Hasil elektroforesis OMP pada lima kelompok bakteri tersebut menunjukkan peningkatan ketebalan pita protein, yaitu semakin tinggi kadar glukosa akan semakin tebal protein yang terekspresi. Ketebalan pita protein OMP $36 \mathrm{kDa}$ dibaca menggunakan program Corel Photo Paint 11. Hasil analisis statistik menunjukkan perbedaan yang tidak bermakna (ANOVA, $p=0,559$ ), namun secara deskriptif terlihat adanya peningkatan ketebalan protein OMP $36 \mathrm{kDa}$ pada perlakuan konsentrasi glukosa yang makin besar. Kesimpulan penelitian ini adalah peningkatan kadar glukosa cenderung akan meningkatkan ekspresi protein AdhO36 S. Typhi.
\end{abstract}

Kata kunci : Adh036, Kadar Glukosa, OMP, Salmonella Typhi

\section{THE INFLUENCE OF GLUCOSE CONCENTRATION TO Adh036 Salmonella Typhi PROTEIN EXPRESSION}

\begin{abstract}
Typhoid fever caused by Salmonella Typhi is one of the most infectious disease which causes patient hospitalization in Indonesia. It needs some research to determine factors contributed to the pathogenicity of $S$. Typhi and glucose concentration is one of the factors. The outer membrane protein (OMP) of $S$. Typhi with molecular weight of $36 \mathrm{kDa}$ named AdhO36 is known as adhesin molecule. Adhesin has function to adhere the bacteria to host cell. This study aimed is to know the influence of glucose with different concentration to the AdhO36 S. Typhi protein expression. There are 5 groups of bacteria that treated with different glucose concentration, $40 \mathrm{mg} / 100 \mathrm{~mL}, 80 \mathrm{mg} / 100 \mathrm{~mL}, 160 \mathrm{mg} / 100 \mathrm{~mL}, 240 \mathrm{mg} / 100 \mathrm{~mL}$, and $320 \mathrm{mg} / 100 \mathrm{~mL}$. The electrophoregram of $S$. Typhi OMP showed that the thickness of AdhO36 protein were in line with glucose concentration, the higher the glucose concentration the thicker the Adh036 protein band. The electrophoregram was analyzed using Corel Photo Paint 11 and statistical analysis showed that there were no significant differences between groups (ANOVA, $p=0.559$ ). However, the thickness of OMP $36 \mathrm{kDa}$ band was increased by increasing glucose consentration, descriptively. The conclusion was glucose concentration tend to increase AdhO36 protein expression.
\end{abstract}

Keywords: Adh036, glucose concentration, OMP, Salmonella Typhi

* Laboratorium Mikrobiologi ,FK UB

** Laboratorium Biokimia, FK UB

*** Program Studi Pendidikan Dokter, FK UB

E-mail:Wiensri238@gmail.com 


\section{Pendahuluan}

Demam tifoid merupakan suatu penyakit infeksi yang disebabkan oleh bakteri Gram negatif Salmonella Typhi ( $S$. Typhi). Demam tifoid ditularkan melalui kontaminasi makanan dan minuman atau biasa disebut oral-fecal transmission. ${ }^{1}$ Pada tahun 2000, terdapat 21,7 juta penderita demam tifoid dan 217.000 kematian karena demam tifoid. ${ }^{2}$ Berdasarkan The Global Burden of Typhoid, Indonesia termasuk dalam kategori high incidence yang apabila diestimasikan terdapat 110 penderita demam tifoid dari 100.000 penduduk setiap tahunnya. ${ }^{3}$ Demam tifoid dan paratifoid berada pada urutan ke-3 dalam peringkat penyakit yang menyebabkan rawat inap di Indonesia di tahun 2010.4

$S$. Typhi merupakan bakteri Gram negatif yang memiliki banyak faktor virulensi yang dapat mempengaruhi patogenesis infeksi dari bakteri ini. ${ }^{5}$ Telah diketahui bahwa $S$. Typhi memiliki protein adhesin yang berasal dari OMP dengan berat molekul $36 \mathrm{kDa}$ yang bernama AdhO36. Protein adhesin ini berfungsi untuk melekat pada sel hospes. Setelah terjadi perlekatan dan invasi ke sel hospes, selanjutnya terjadilah infeksi dari bakteri ini. Imunisasi protein AdhO36 secara oral telah terbukti meningkatkan protektivitas dalam menghambat perlekatan $S$. Typhi pada usus mencit. Lebih lanjut dilaporkan bahwa protein AdhO36 bersifat imunogenik yaitu mampu merangsang imunitas humoral baik mukosal maupun sistemik. Protein Adh036 juga mampu merangsang imunitas seluler. ${ }^{6}$

Diabetes mellitus (DM) adalah sindroma metabolik yang ditandai dengan peningkatan kadar glukosa darah. Kondisi hiperglikemia ini adalah kondisi yang tidak menular dan akan meningkat terus jumlahnya di masa yang akan datang. WHO membuat perkiraan bahwa pada tahun 2025 akan ada 300 juta orang yang menderita diabetes melitus di seluruh dunia. ${ }^{7}$ Pasien dengan kadar glukosa darah yang tinggi lebih rentan terhadap berbagai macam infeksi. Kadar glukosa yang melebihi 150 $\mathrm{mg} / \mathrm{dL}$ berkaitan dengan terjadinya pneumonia pada pasien kritis. ${ }^{8}$ Selain itu, kondisi hiperglikemia berkaitan dengan komplikasi setelah operasi kolektomi. ${ }^{9}$ Hiperglikemia juga berhubungan dengan durasi opname pada pasien post operasi abdomen. ${ }^{10}$ Penyebab meningkatnya infeksi pada penderita hiperglikemia adalah melalui terbentuknya biofilm. Massa biofilm dari bakteri akan meningkat seiring dengan meningkatnya kadar glukosa. ${ }^{11} \mathrm{~S}$. Typhi adalah salah satu bakteri yang memproduksi biofilm, sehingga virulensi dari Salmonella akan meningkat seiring dengan bertambahnya kadar glukosa. Biofilm terbentuk atas berbagai macam struktur, salah satunya adalah OMP. Sebelum terbentuknya biofilm tentunya Salmonella harus melekat kepada hospes melalui faktor adhesin.

Oleh karena itu, pada penelitian ini ingin diketahui ekspresi protein AdhO36 sebagai faktor adhesin akibat perubahan kadar glukosa pada media kultur. Protein Adh036 yang merupakan OMP S.Typhi diduga mengalami perubahan ekspresi pada lingkungan dengan kadar glukosa yang berbeda sehingga turut mempengaruhi proses adhesi dan invasi. Ekspresi protein dapat dideteksi dengan melihat ketebalan pita protein hasil elektroforesis SDS-PAGE.

\section{Bahan dan Metode}

Desain Penelitian:

Desain penelitian yang digunakan adalah penelitian eksperimental laboratorik. Pengaruh kadar glukosa akan diamati pada lima perlakuan yang diinkubasi dalam medium Luria Bertani Broth. Kadar glukosa masing-masing perlakuan yaitu perlakuan 1 
(40 mg/100mL), perlakuan $2(80 \mathrm{mg} / 100 \mathrm{~mL})$, perlakuan $3(160 \mathrm{mg} / 100 \mathrm{~mL})$, perlakuan 4 $(240 \mathrm{mg} / 100 \mathrm{~mL})$, dan perlakuan 5 (320 $\mathrm{mg} / 100 \mathrm{~mL}$ ).

Sampel Penelitian:

Sampel penelitian yang digunakan adalah bakteri $S$. Typhi isolat 444-D yang didapatkan dari Laboratorium Mikrobiologi, Fakultas Kedokteran, Universitas Brawijaya, Malang, Jawa Timur.

Definisi Operasional:

- Bakteri S. Typhi diambil dari stock bakteri S. Typhi di Laboratorium Mikrobiologi FKUB yang berasal dari darah penderita demam tifoid di RSU dr. Saiful Anwar Malang.

- Protein Adh036 adalah outer membrane protein (OMP) $S$. Typhi dengan berat molekul sekitar $36 \mathrm{kDa}$ pada SDS-PAGE yang diisolasi menggunakan SDS terhadap permukaan bakteri S. Typhi.

\section{Hasil}

Identifikasi S. Typhi:

Sebelum memberi perlakuan glukosa, terlebih dahulu dilakukan identifikasi bakteri S.Typhi yang tersedia di Laboratorium Mikrobiologi Fakultas Kedokteran Universitas Brawijaya. S.Typhi yang digunakan berasal dari darah penderita demam tifoid di RSU dr. Saiful Anwar Malang. Identifikasi bakteri dilakukan melalui 4 tahap. Tahap pertama adalah pengecatan Gram yang menunjukkan bakteri berbentuk batang berwarna merah yaitu ciri khas Gram negatif (Gambar 1). Tahap kedua yaitu penanaman pada medium MacConkey yang menunjukkan koloni bulat, tepi tajam, dan permukaan halus, tidak berwarna, dan berdiameter 1-3 mm (Gambar 2). Tahap ketiga yaitu penanaman pada medium Bismuth Sulfite Agar (BSA) yang menunjukkan gambaran khas $S$. Typhi yaitu koloni berwarna hitam (black jet colony) karena S. Typhi menghasilkan $\mathrm{H}_{2} \mathrm{~S}$ (Gambar 3). Tahap keempat yaitu test Microbact $12 \mathrm{~A}$ yang memberikan hasil positif pada lysin, ornitin, glukosa, H2S, manitol, xylose, dan citrat. Test microbact $12 \mathrm{~A}$ memberikan hasil negatif pada ONPG, indole, urease, vogesproskauer serta TDA (Gambar 4).

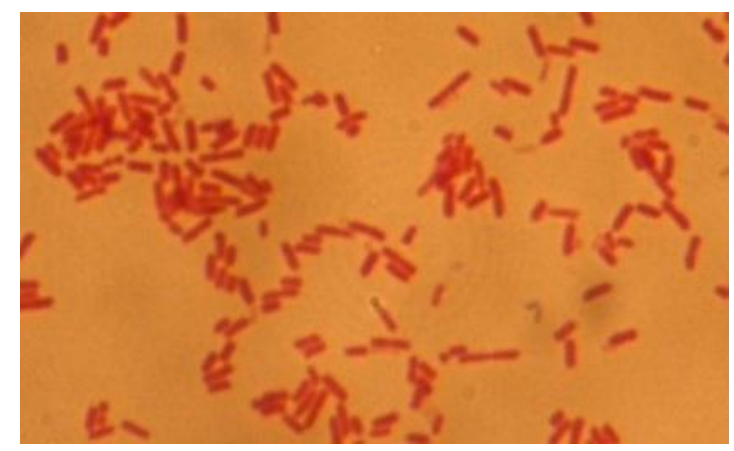

Gambar 1. Morfologi bakteri Gram negatif S. Typhi berbentuk batang berwarna merah (1000x). 


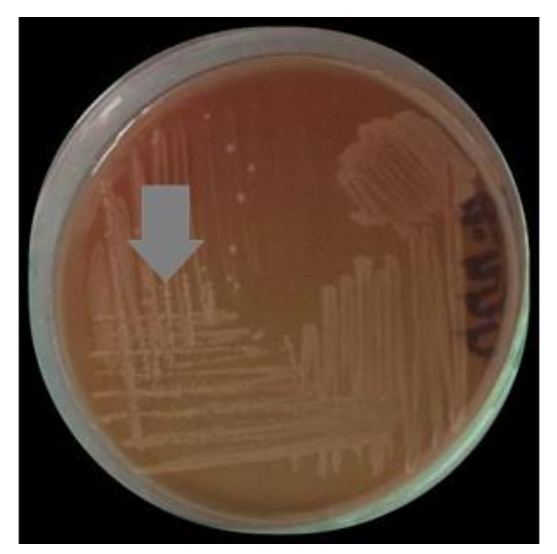

Gambar 2. Koloni S.Typhi pada medium MacConkey berbentuk bulat dan tidak berwarna.

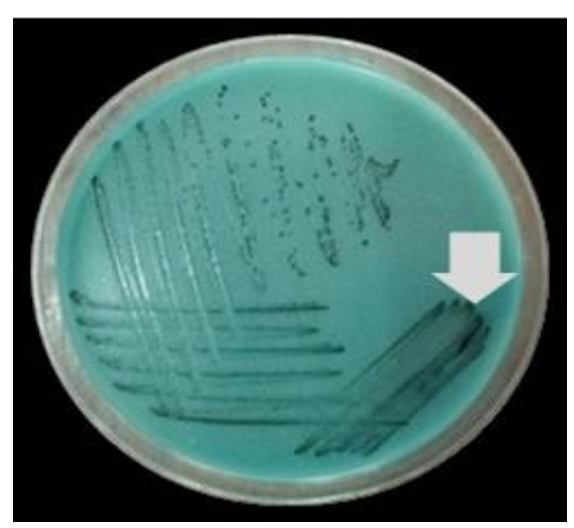

Gambar 3. Koloni bakteri S. Typhi pada medium bismuth sulfite agar berwarna hitam (Black Jet Colony).

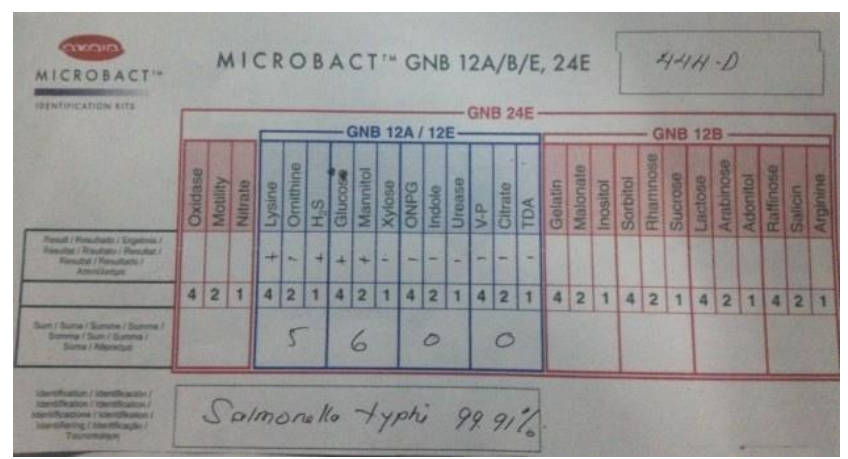

Gambar 4. Hasil tes microbact 12A S.Typhi

Profil OMP Setelah Perlakuan Glukosa dengan SDS-PAGE:

Penelitian ini dilakukan sebanyak empat kali pengulangan sesuai dengan desain penelitian. Protein OMP S.Typhi pada berbagai kelompok perlakuan dielektroforesis pada gel SDS-PAGE untuk mengetahui profil pitanya (Gambar 5). 

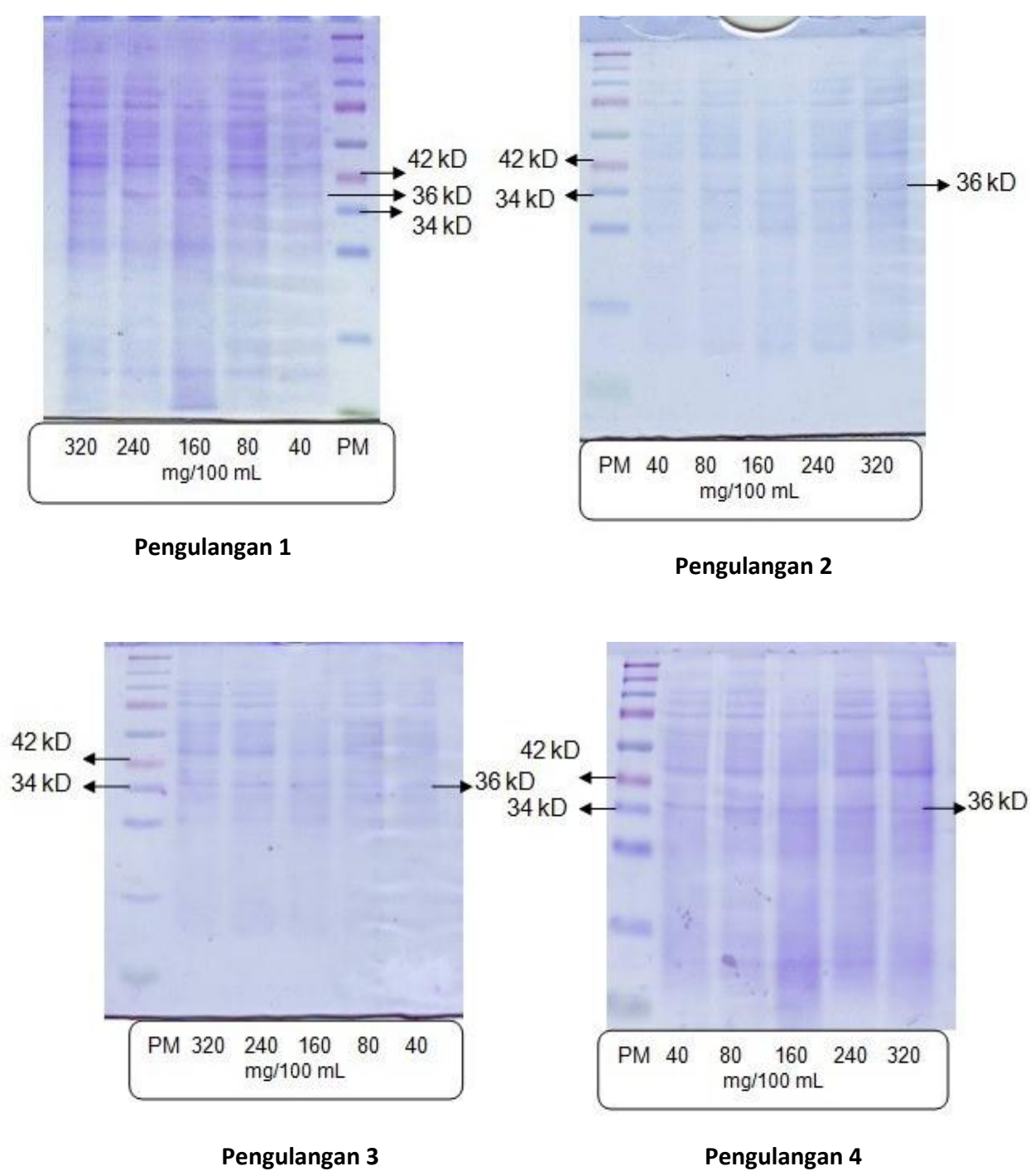

Gambar 5. Profil OMP S. Typhi setelah diberi perlakuan glukosa. Keterangan: protein marker (PM), $40 \mathrm{mg} / 100 \mathrm{~mL}$ (perlakuan 1), $80 \mathrm{mg} / 100 \mathrm{~mL}$ (perlakuan 2), $160 \mathrm{mg} / 100 \mathrm{~mL}$ (perlakuan 3), $240 \mathrm{mg} / 100 \mathrm{~mL}$ (perlakuan 4), $320 \mathrm{mg} / 100 \mathrm{~mL}$ (perlakuan 5).

Pengaruh Kadar Glukosa terhadap Ekspresi Protein AdhO36:

Hasil elektroforesis yang telah diperoleh kemudian diamati secara visual dan dinilai ketebalannya menggunakan aplikasi Corel Photo-Paint 11, sehingga bisa dikonversikan dalam bentuk angka (Tabel 1).
Angka yang muncul tersebut berupa nilai means yaitu perbandingan kontras warna yang diukur dengan warna hitam. Semakin kecil means menunjukkan semakin tidak kontras warna yang diukur dengan warna hitam (mendekati hitam) atau semakin tebal pita yang diukur. 
Tabel 1. Hasil pengukuran ketebalan pita protein AdhO36 menggunakan Corel Photo Paint 11

\begin{tabular}{clllll}
\hline \multirow{2}{*}{ Pengulangan } & \multicolumn{5}{c}{ Ketebalan Protein } \\
\cline { 2 - 6 } & $\begin{array}{c}40 \mathrm{mg} / 100 \mathrm{~mL} \\
(\mathrm{P} 1)\end{array}$ & $\begin{array}{l}80 \mathrm{mg} / 100 \mathrm{~mL} \\
(\mathrm{P} 2)\end{array}$ & $\begin{array}{l}160 \mathrm{mg} / 100 \mathrm{~mL} \\
(\mathrm{P} 3)\end{array}$ & $\begin{array}{l}240 \mathrm{mg} / 100 \mathrm{~mL} \\
(\mathrm{P} 4)\end{array}$ & $\begin{array}{l}320 \mathrm{mg} / 100 \mathrm{~mL} \\
(\mathrm{P} 5)\end{array}$ \\
\hline 1 & 186.43 & 172.95 & 169.07 & 172.12 & 167.84 \\
\hline 2 & 201.77 & 199.22 & 200.36 & 196.29 & 187.37 \\
\hline 3 & 196.80 & 192.15 & 189.99 & 190.46 & 188.98 \\
\hline 4 & 184.75 & 182.10 & 175.02 & 174.60 & 170.39 \\
\hline Rerata $\pm(S D)$ & $192.44+(8.19)$ & $186.60+(11.49)$ & $183.61+(14.21)$ & $183.37+(11.84)$ & $178.65+(11.07)$ \\
\hline
\end{tabular}

Nilai rerata dari angka means pada masing-masing pengulangan yang didapat dari pengukuran ketebalan pita protein Adh036 dengan menggunakan Corel
Photo-Paint 11 dapat ditampilkan dalam bentuk diagram batang seperti terlihat pada Gambar 6.

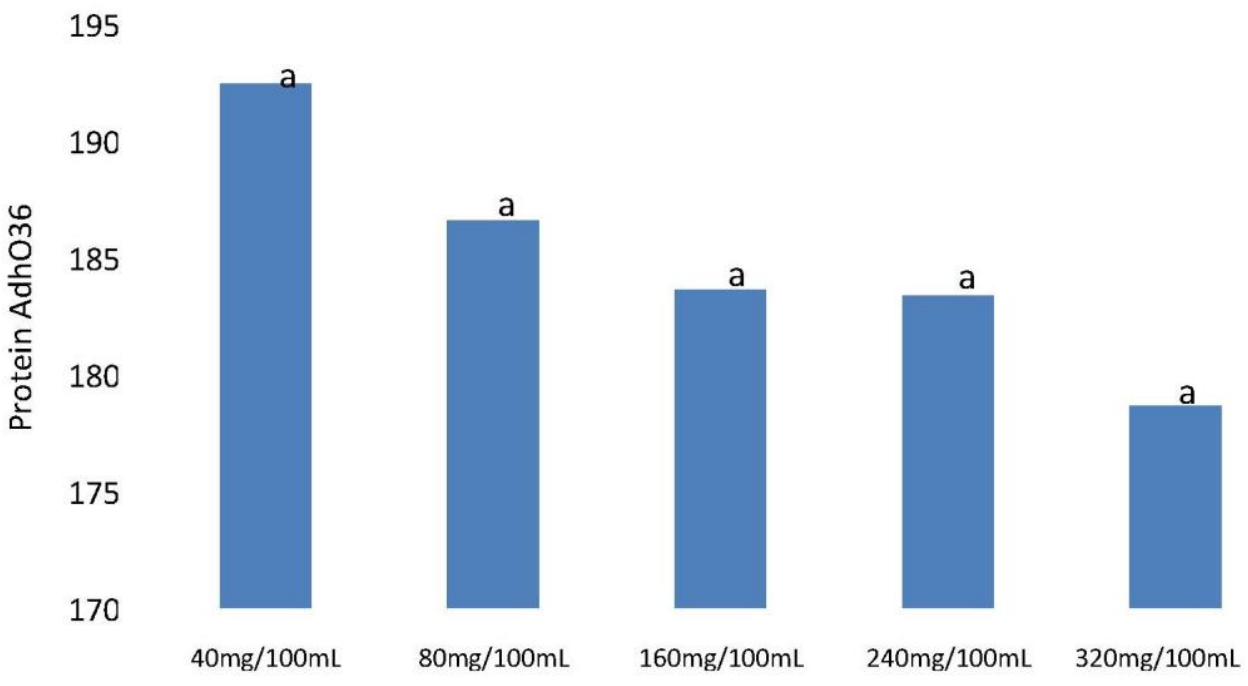

Gambar 6. Rerata nilai means ketebalan pita protein AdhO36 dengan Corel Photo-Paint 11. Keterangan : Huruf yang sama (a) menunjukkan tidak berbeda secarabermakna

Berdasarkan Gambar 6 diketahui bahwa perlakuan glukosa $320 \mathrm{mg} / 100 \mathrm{~mL}$ menunjukkan nilai means paling kecil yang berarti memiliki kepekatan warna yang paling besar. Hal ini menunjukkan bahwa pada perlakuan $320 \mathrm{mg} / 100 \mathrm{~mL}$ didapatkan protein Adh036 paling banyak yang diketahui dari pita proteinnya yang paling tebal. Berdasarkan nilai means di atas diketahui pita protein Adh036 paling tebal terdapat pada perlakuan kadar glukosa 320 $\mathrm{mg} / 100 \mathrm{~mL}$, kemudian $240 \mathrm{mg} / 100 \mathrm{~mL}, 160$ $\mathrm{mg} / 100 \mathrm{~mL}, 80 \mathrm{mg} / 100 \mathrm{~mL}$, dan yang paling tipis pada perlakuan $40 \mathrm{mg} / 100 \mathrm{~mL}$.

Berdasarkan uji normalitas menggunakan Shapiro-Wilk pada rerata means masing-masing kelompok perlakuan, didapatkan nilai signifikasi ketebalan protein Adh036 $p>0,05$, yang berarti data hasil 
penelitian terdistribusi normal. Berdasarkan analisis uji homogeneity of variances didapatkan taraf signifikansi menunjukkan ketebalan protein Adh036 S. Typhi sebesar 0,442 , sehingga disimpulkan $p>0,05$ yang berarti data hasil penelitian homogen.

Data hasil penelitian terdistribusi normal dan homogen, sehingga dapat dilanjutkan dengan analisis one-way ANOVA yang mendapatkan nilai signifikansi sebesar 0,559 , sehingga disimpulkan $p>0,05$ yang berarti tidak terdapat perbedaan yang bermakna antara kelompok perlakuan.

\section{Pembahasan}

Penelitian ini dilakukan untuk mengetahui pengaruh kadar glukosa terhadap ekspresi protein Adh036 S. Typhi. Setelah dilakukan identifikasi bakteri, dilakukan kultur dengan lima perlakuan yang berbeda kadar glukosanya. Kelompok perlakuan pertama dengan kadar glukosa 40 $\mathrm{mg} / 100 \mathrm{~mL}$, perlakuan kedua dengan kadar glukosa $80 \mathrm{mg} / 100 \mathrm{~mL}$, perlakuan ketiga dengan kadar glukosa $160 \mathrm{mg} / 100 \mathrm{~mL}$, kelompok perlakuan keempat dengan kadar glukosa $240 \mathrm{mg} / 100 \mathrm{~mL}$ dan kelompok perlakuan kelima dengan kadar glukosa 320 $\mathrm{mg} / 100 \mathrm{~mL}$. Masing-masing perlakuan dikultur pada media kultur Luria Bertani Broth yang diinkubasikan pada suhu $37{ }^{\circ} \mathrm{C}$ selama $2 \times 24$ jam.

Dalam penelitian ini dilakukan pembandingan ketebalan pita protein Adh036 pada masing- masing kelompok perlakuan setelah proses pemisahan protein dengan metode SDS-PAGE. Secara kasat mata, tampak bahwa ketebalan pita protein makin meningkat sebanding dengan bertambahnya kadar glukosa. Pada Tabel 1 diketahui bahwa nilai rerata means ketebalan protein berkurang sebanding dengan peningkatan kadar glukosa, yang artinya ketebalan protein AdhO36 meningkat sebanding dengan peningkatan kadar glukosa. Namun demikian, secara statistik tidak berbeda secara signifikan. Hal ini kemungkinan disebabkan karena banyaknya factor yang mempengaruhi ekspresi protein AdhO36 seperti pH medium, osmolaritas, dan glikasi protein.

Perbedaan kadar glukosa media kultur pada penelitian ini mengacu pada kadar glukosa darah manusia. Berdasarkan Konsensus Pengelolaan dan Pencegahan Diabetes Melitus Tipe 2 di Indonesia yang disusun oleh Perhimpunan Endokrinologi Indonesia, kadar glukosa darah normal puasa adalah kurang dari $100 \mathrm{mg} / \mathrm{dL}$. Pada keadaan puasa, kadar GDPT (Glukosa Darah Puasa Terganggu) adalah 100-125 $\mathrm{mg} / \mathrm{dL}$. Diagnosis Diabetes Melitus ditegakkan bila kadar gula darah puasa $\geq 126 \mathrm{mg} / \mathrm{dL}$ dengan gejala klasik DM. Pada pemeriksaan glukosa darah TTGO (Tes Toleransi Glukosa Oral) dengan cara mengukur kadar glukosa darah 2 jam setelah pemberian 75 gram glukosa, kadar TGT (Toleransi Glukosa Terganggu) adalah 140-199 mg/dL. Sedangkan diagnosis Diabetes Melitus pada TTGO adalah $\geq 200 \mathrm{mg} / \mathrm{dL}$. Kadar hipoglikemia atau glukosa darah rendah ditandai dengan menurunnya kadar glukosa darah $<60$ $\mathrm{mg} / \mathrm{dL}$. Salah satu komplikasi diabetes mellitus adalah ketoasidosis diabetik yang salah satunya ditandai dengan peningkatan glukosa darah $\geq 300 \mathrm{mg} / \mathrm{dL}$. Berdasarkan uraian di atas, dipilih kadar glukosa media kultur yaitu $40 \mathrm{mg} / 100 \mathrm{~mL}$, $80 \mathrm{mg} / 100 \mathrm{~mL}, 160 \mathrm{mg} / 100 \mathrm{~mL}, 240$ $\mathrm{mg} / 100 \mathrm{~mL}$ dan $320 \mathrm{mg} / 100 \mathrm{~mL}$ yang mewakili keadaan hipoglikemia, keadaan normal glukosa darah, keadaan TGT, keadaan diabetes melitus dan juga keadaan ketoasidosis diabetik mulai muncul. Hal ini untuk mengetahui pengaruh kadar glukosa pada manusia dan pengaruhnya terhadap ekspresi protein Adh036. 
Pada lingkungan dengan keadaan glukosa yang tinggi, perlekatan dari Enterobacteriaceae Eschericia coli terhadap epitel mengalami peningkatan 5 kali lipat dibanding dengan kadar glukosa normal. Kemampuan clearance bakteri juga mengalami penurunan pada tikus dengan diabetes melitus. Kedua hal tersebut berkontribusi pada patogenesis dan perpanjangan waktu infeksi. Bakteri $S$. Typhi termasuk dalam Enterobacteriaceae sehingga peningkatan ekspresi AdhO36 sebagai salah satu faktor adhesin bakteri dapat dihubungkan dengan peningkatan kadar glukosa lingkungan. ${ }^{12}$

Keadaan hiperglikemia dapat meningkatkan endothelial permeability dan mengubah struktur membran basalis epitel pada bakteri Gram negarif Helicobacter pylori. Peningkatan adhesi dari Helicobacter pylori terhadap epitel secara signifikan meningkat pada kadar glukosa $200 \mathrm{mg} / \mathrm{dL}$ jika dibandingkan dengan kadar glukosa $100 \mathrm{mg} / \mathrm{dL}$ dan $150 \mathrm{mg} / \mathrm{dL}$. Pertumbuhan bakteri ini juga meningkat pada kadar glukosa yang lebih tinggi. $S$. Typhi termasuk bakteri Gram negatif sehingga hal ini bisa diasosiasikan dengan peningkatan ketebalan protein AdhO36 sebagai faktor adhesi. ${ }^{13}$

Dalam penelitian ini ekpresi protein Adh036 diasumsikan juga dipengaruhi oleh glikasi protein. Protein mampu membentuk ikatan kovalen dengan glukosa tanpa bantuan enzim yang disebut dengan glikasi. Pada kadar glukosa yang makin tinggi dapat terjadi glikasi protein sehingga ketebalan di posisi $36 \mathrm{kDa}$ menjadi tidak jelas atau justru pindah pada posisi sekitar 74 kDa. Pada Gambar 5 tampak ketebalan protein di sekitar molekul $74 \mathrm{kDa}$ yang menunjukkan respons terhadap perubahan kadar glukosa.

Kekurangan pada penelitian ini yaitu tidak bisa menggunakan jumlah bakteri yang sangat akurat pada setiap perlakuannya, sehingga dapat mempengaruhi ekspresi protein AdhO36. Apabila semakin banyak jumlah bakteri maka protein AdhO36 yang terekspresi juga meningkat. Pada penelitian ini hanya digunakan satu isolat $S$. Typhi, sehingga belum diketahui apakah isolat $S$. Typhi yang lain juga merespons terhadap perubahan kadar glukosa. Kekurangan lain pada penelitian ini adalah digunakannya pewarna yang kurang sensitif yaitu coomassie blue.

Pada Gambar 6 ditunjukkan ekspresi protein Adh036 terhadap kadar glukosa. Meskipun secara statistik tidak bermakna namun secara visual ada kecederungan peningkatan ketebalan protein AdhO36. Tidak hanya protein Adh036, namun OMP secara keseluruhan tampak lebih tebal seiring dengan meningkatnya kadar glukosa seperti tampak pada elektroforegram pada Gambar 5. Hal ini menunjukkan adanya peningkatan faktor virulensi dari bakteri $S$. Typhi melalui peningkatan faktor adhesi. Jadi, bakteri akan melekat lebih kuat pada usus penderita dan lebih mudah melakukan invasi. Setelah terjadinya invasi tentunya akan terjadi infeksi dari bakteri $S$. Typhi.

\section{Kesimpulan}

Dari hasil penelitian mengenai pengaruh kadar glukosa terhadap ekspresi protein Adh036 bakteri $S$. Typhi, dapat disimpulkan bahwa peningkatan kadar glukosa cenderung meningkatkan ekspresi protein AdhO36 bakteri S. Typhi.

\section{Saran}

Adapun saran untuk penelitian selanjutnya adalah perlu mengakuratkan jumlah bakteri secara lebih tepat dan menggunakan lebih dari satu isolat $S$. Typhi. Pada pewarnaan SDS-PAGE dapat menggunakan pewarna yang lebih sensitif 
seperti silver staining. Dapat dilakukan uji adhesi protein AdhO36 yang diinkubasikan pada kadar glukosa yang berbeda pada enterosit mencit. Untuk pengembangan vaksin berbasis protein adhesin, hasil penelitan ini dapat digunakan sebagai pertimbangan bahwa peningkatan kadar glukosa bersifat menaikkan ekspresi protein Adh036, sehingga pemberian vaksin per oral sebaiknya mempertimbangkan kadar glukosa pasien.

\section{Daftar Pustaka}

1. Nelwan HR. Tata Laksana Terkini Demam Tifoid. Cermin Dunia Kedokteran. 2012; 39(4):247 - 250.

2. Crump JA, Luby SP, Mintz ED. The Global Burden of Typhoid Fever. Bulletin of the World Health Organization. 2004; 82(5):346-353.

3. (WHO) World Health Organization. Background Document: The Diagnosis, Treatment, and Prevention of Typhoid Fever. (Online). 2003. www.who.int/vaccines-documents/. Diakses 11 Desember 2013.

4. Kementerian Kesehatan Republik Indonesia. Profil Data Kesehatan Indonesia Tahun 2011. Jakarta: Kementerian Kesehatan Republik Indonesia. 2012.

5. Dzen SM, Roeskitiningsih, Santoso S, Winarsih S. Bakteriologi Medik. Surabaya: Penerbit Putra Media Nusantara. 2010. HIm 225 - 237.

6. Winarsih S. Imunitas Seluler dan Protektivitas in vivo Protein AdhO36 Salmonella Typhi. Disertasi. Malang: Program Pasca Sarjana Universitas
Brawijaya. 2005.

7. Suyono S. Diabetes Mellitus di Indonesia. Di dalam: Sudoyo AW, Setiyohadi B, Alwi I, Simadibrata M, Setiati $S$ (Editor). Buku Ajar IImu Penyakit Dalam. Jakarta: Interna Publishing. 2009.

8. Kraft $R$, Hemdon DN, Mlcak RP, Finnerty CC, Cox RA, Williams FN, Jeschke MG. Bacterial Respiratory Tract Infections are Promoted by Systemic Hyperglycemia after Severe Burn Injuries in Pediatric Patients. Burns. 2014; 40(3):428-435. doi:10.1016/j.burns.2013.07.007.

9. Jackson RS, Amdur RL, White JC, Macsata RA. Hyperglycemia is Associated with Increase Risk of Morbidity and Mortality after Colectomy for Cancer. J Am Coll Surg. 2012;214(1):68-

80.doi:10.1016/j.jamcollsurg.2011.09.016 .Epub

10.Wu Y et al. Hyperglycemia and Its Association with Clinical Outcomes in the Pediatric Intensive Care Unit after Abdominal Surgery. J Pediatr Surg. 2013; 48(4):801-805.

11. Waldrop R. McLaren A. Calara F. McLemore R. Biofilm Growth has a Threshold Response to Glucose in vitro. Clin Orthop Relat Res. 2014; 472(11):3305-10. doi: 10.1007/s11999014-3538-5.

12. Ozer A. Increased Bacterial Adherence and Decreased Bacterial Clearance in Urinary Tract Infections with Diabetes Mellitus. Ohio: Case Western Reserve University.2013. 